\title{
Ongoing HIV transmission following a large outbreak among people who inject drugs in Athens, Greece (2014-2020)
}

Sotirios Roussos ${ }^{1,2}$, Dimitrios Paraskevis ${ }^{1}$, Mina Psichogiou ${ }^{3}$, Evangelia Georgia Kostaki $^{1}$, Eleni Flountzi ${ }^{1}$, Theodoros Angelopoulos ${ }^{2}$, Savvas Chaikalis ${ }^{2}$, Martha Papadopoulou $^{2,3}$, Ioanna D Pavlopoulou ${ }^{4}$, Meni Malliori ${ }^{5}$, Eleni Hatzitheodorou ${ }^{6}$, Magdalini Pylli ${ }^{6}$, Chrissa Tsiara $^{6}$, Dimitra Paraskeva ${ }^{6}$, Apostolos Beloukas $^{7,8}$, George Kalamitsis $^{9}$, Angelos Hatzakis ${ }^{1,2}$, Vana Sypsa ${ }^{1}$

\section{Affiliations:}

${ }^{1}$ Department of Hygiene, Epidemiology and Medical Statistics, Medical School, National and Kapodistrian University of Athens, Athens, Greece

${ }^{2}$ Hellenic Scientific Society for the Study of AIDS STDs and Emerging Diseases, Athens, Greece

${ }^{3}$ First Department of Internal Medicine, Medical School, National and Kapodistrian University of Athens, Athens, Greece

${ }^{4}$ Pediatric Research Laboratory, Faculty of Nursing, National and Kapodistrian University of Athens, Athens, Greece

${ }^{5}$ Psychiatric Department, National and Kapodistrian University of Athens, Medical School, Athens, Greece

${ }^{6}$ Hellenic National Public Health Organization, Maroussi, Greece

${ }^{7}$ Department of Biomedical Sciences, University of West Attica, Athens, Greece NOTE: This preprint reports new research that has not been certified by peer review and should not be used to guide clinical practice. 
medRxiv preprint doi: https://doi.org/10.1101/2021.06.24.21258830; this version posted June 25, 2021. The copyright holder for this preprint (which was not certified by peer review) is the author/funder, who has granted medRxiv a license to display the preprint in perpetuity.

All rights reserved. No reuse allowed without permission.

${ }^{8}$ Institute of Infection and Global Health, University of Liverpool, Liverpool, UK

${ }^{9}$ Hellenic Liver Patient Association "Prometheus", Athens, Greece

Key words: PWID; HIV; Outbreak; Incidence; Greece

\section{Corresponding author:}

Vana Sypsa

Associate Professor of Epidemiology and Medical Statistics

Department of Hygiene, Epidemiology and Medical Statistics, School of Medicine

National and Kapodistrian University of Athens

75, Mikras Asias street, 11527 Athens, Greece

Tel.: +30 2107462193

E-mail: vsipsa@med.uoa.gr 
medRxiv preprint doi: https://doi.org/10.1101/2021.06.24.21258830; this version posted June 25, 2021. The copyright holder for this preprint (which was not certified by peer review) is the author/funder, who has granted medRxiv a license to display the preprint in perpetuity.

All rights reserved. No reuse allowed without permission.

\begin{abstract}
Background

The HIV outbreak among People Who Inject Drugs (PWID) in Athens, Greece in 20112013 was the largest recent epidemic in Europe and North America. We aim to provide updated estimates of HIV prevalence and incidence.
\end{abstract}

\title{
Methods
}

Two community-based HIV/hepatitis C programs on active PWID were implemented in 2012-2013 (ARISTOTLE, N=3,320) and 2018-2020 (ARISTOTLE HCV-HIV, $\mathrm{N}=1,635)$ through consecutive respondent-driven sampling recruitment rounds. PWID were uniquely identified across rounds/programs. We evaluated trends in HIV prevalence, socioeconomic characteristics, and injection practices in PWID participating in both periods and estimated HIV incidence in a cohort of seronegative PWID. Molecular sequencing and phylogenetic analysis were performed in HIV seroconverters.

\section{Results}

HIV prevalence (95\% CI) increased from $14.2 \%$ (11.7\%-17.1\%) in 2012-2013 to $22.0 \%$ $(19.0 \%-25.3 \%)$ in $2018-2020(\mathrm{p}<0.001)$. There was a deterioration of socioeconomic characteristics such as homelessness (from 16.2\% to 25.6\%, p<0.001), a shift in the use of cocaine (from $16.6 \%$ to $28.1 \%$, $\mathrm{p}<0.001$ ), reduced access to free syringes (past 12 months: $51.8 \%$ and $45.1 \%, \mathrm{p}=0.005$ ) and to HIV testing (past 12 months: $50.9 \%$ and 49.4\%). HIV incidence (95\% CI) in 2014-2015, 2016-2017 and 2018-February 2020 was $2.10(1.41-3.14), 2.04(1.34-3.10)$ and $1.52(0.84-2.75)$ new cases/100 personyears, respectively. Younger age, lower educational level, larger injection network and 
medRxiv preprint doi: https://doi.org/10.1101/2021.06.24.21258830; this version posted June 25, 2021. The copyright holder for this preprint (which was not certified by peer review) is the author/funder, who has granted medRxiv a license to display the preprint in perpetuity.

All rights reserved. No reuse allowed without permission.

daily injecting were risk factors for HIV seroconversion. Almost $9 \%$ of HIV seroconversions occurred within a newly expanding phylogenetic cluster.

\section{Conclusion}

The ongoing HIV transmission among PWID in Athens provides empirical evidence that the current levels of prevention and treatment are inadequate to control the epidemic, leading to expansion of the pool of infected PWID and a rise in HIV prevalence. Re-evaluation of prevention and treatment programs is urgently needed.

\section{Funding}

European Union and Greek national funds, Gilead Sciences, AbbVie, Hellenic Scientific Society for the Study of AIDS, STDs and Emerging Diseases, MSD, and Gilead Hellas. 
medRxiv preprint doi: https://doi.org/10.1101/2021.06.24.21258830; this version posted June 25,2021 . The copyright holder for this preprint (which was not certified by peer review) is the author/funder, who has granted medRxiv a license to display the preprint in perpetuity.

All rights reserved. No reuse allowed without permission.

\section{Introduction}

People who inject drugs (PWID) constitute a population with a high burden of HIV infection ${ }^{1}$. The first outbreaks among PWID were recorded in the 1980s-1990s in Europe and North America and were associated with a high prevalence of syringe sharing and PWID being highly interconnected via their injection networks ${ }^{2}$. In response to these epidemics, harm reduction services, such as needle and syringe (NSP) and opioid substitution treatment (OST) programs, were introduced and expanded. Since the mid-1990s, no epidemics in Europe were recorded, with the exception of HIV outbreaks occurring in countries of the former Soviet Union ${ }^{2}$. The situation changed after 2010 when a series of HIV epidemics were documented once again in Europe and North America ${ }^{3}$.

The largest of these outbreaks occurred in Athens, Greece between 2011-2013³ where HIV prevalence in the population of PWID increased from less than $1 \%$ in 2010 to $16.5 \%$ in $2013^{4}$. This outbreak occurred within the context of low coverage harm reduction programs and financial crisis ${ }^{5,6}$. As soon as it was recognized, there were efforts to expand NSP and OST programs. In addition, a community-based intervention using peer-driven chain referral was used to recruit a large portion of the PWID population rapidly, test them, and link patients to HIV care (ARISTOTLE program). ARISTOTLE reached an estimated population coverage of $88 \%$ and during its implementation, HIV incidence decreased by $78 \%{ }^{4,7}$.

Since then, the number of newly diagnosed HIV cases among PWID in Greece declined but never returned to pre-outbreak levels ${ }^{8}$. In 2018-2020, a program with a similar design was implemented in Athens, aiming to enroll a high number of PWID and 
medRxiv preprint doi: https://doi.org/10.1101/2021.06.24.21258830; this version posted June 25, 2021. The copyright holder for this preprint (which was not certified by peer review) is the author/funder, who has granted medRxiv a license to display the preprint in perpetuity.

All rights reserved. No reuse allowed without permission.

increase diagnosis and treatment for HIV and hepatitis C infection (ARISTOTLE HCVHIV).

In this analysis, we combine the data from the two programs in order to: a) assess HIV incidence and associated risk factors among PWID in Athens during 2014-2020 (i.e., the period following the outbreak), b) estimate the change in HIV prevalence, drug use behaviours and access to prevention services over time in a sample of PWID participating in both periods (2012-2013 and 2018-2020).

\section{Methods}

\section{Design of ARISTOTLE and ARISTOTLE HCV-HIV programs}

ARISTOTLE (August 2012-December 2013) and ARISTOTLE HCV-HIV (April 2018-February 2020) are community-based programs aiming at increasing the diagnosis and linkage to care for HIV and HIV/HCV, respectively, in the population of PWID in Athens. A common design was used in the two programs. Eligible participants were people 18 years or older who had injected drugs in the past 12 months and resided in Athens metropolitan area. The programs were based in a fixed location in the centre of Athens and employed Respondent-Driven Sampling (RDS) to recruit participants. RDS is a peer-driven chain referral where recruitment begins with a limited number of initial recruits ('seeds'); individuals receive coupons and are asked to draw from their existing social networks to identify up to $3-5$ potential recruits, who then present themselves to the program site $^{9}$. A dual incentive system was used, in which participants receive incentives for participating (primary incentives) as well as for recruiting others (secondary incentives). Unique numbers were recorded on the coupons and allowed the recruiter to be linked to his/her recruits. 
medRxiv preprint doi: https://doi.org/10.1101/2021.06.24.21258830; this version posted June 25, 2021. The copyright holder for this preprint (which was not certified by peer review) is the author/funder, who has granted medRxiv a license to display the preprint in perpetuity.

All rights reserved. No reuse allowed without permission.

After obtaining written informed consent, eligible participants were tested for HIV (and HCV in ARISTOTLE HCV-HIV). A questionnaire was used to collect information on participants' sociodemographic characteristics, injection, and sexual behaviour as well as on access to HIV testing, treatment, and prevention programs. As reporting HIV cases and antiretroviral treatment initiation is mandatory in Greece, HIV cases were reported to the National Public Health Organisation; newly diagnosed cases were identified and prioritised for linkage to HIV care by dedicated staff.

Both programs were implemented in multiple consecutive recruitment rounds with a short break in-between (5 rounds in ARISTOTLE 2012-2013, 2 rounds in ARISTOTLE HCV-HIV 2018-2020). PWID could participate in multiple rounds but only once in each round. As a result, multiple HIV tests and questionnaires were available over time for the majority of participants (Figure 1). Participants provided written informed consent and the two first initials of their name and surname. These initials along with the full birth date and information on gender were used to identify the participants across recruitment rounds and programs. Participants could also provide their full names to allow the study personnel to issue or seek their social security number.

\section{Outcome measures}

The main outcome measure in our analysis was HIV infection status. This was derived from laboratory testing of blood samples using a microparticle enzyme immunoassay anti-HIV-1/2 (AxSYM HIV-1/2 gO; Abbott) and HIV-1/HIV-2 confirmation by Western Blot (MP Diagnostics) or Geenius HIV 1/2 Confirmatory Assay.

\section{HIV prevalence}

We estimated HIV prevalence in 2012-2013 and 2018-2020 in a subset of 681 PWID who participated in both programs (prevalence cohort) (Figure 1). For those who 
medRxiv preprint doi: https://doi.org/10.1101/2021.06.24.21258830; this version posted June 25, 2021. The copyright holder for this preprint (which was not certified by peer review) is the author/funder, who has granted medRxiv a license to display the preprint in perpetuity.

All rights reserved. No reuse allowed without permission.

participated in multiple rounds within each program, the last available HIV test result was used for each period.

\section{HIV incidence}

To estimate HIV incidence during the period 2014-2020, we analysed 699 initially seronegative participants with multiple samples and at least one sample collected in 2018-2020 (incidence cohort) (Figure 1). For PWID participating in ARISTOTLE 2012-2013, we considered only those who tested HIV(-) in their last visit to the program as we were interested in seroconversions following the outbreak period. More specifically, we included in the analysis: 1) N=582 PWID for whom the last available HIV test result in 2012-2013 was negative and subsequently participated in one or both rounds of ARISTOTLE HCV-HIV in 2018-2020 (2-3 HIV test results available), 2) N=117 PWID who participated only in ARISTOTLE HCV-HIV 2018-2020 (both rounds) and were initially HIV-negative (two HIV test results available) (Table 1).

The HIV incidence rate was calculated as the total number of HIV seroconversions divided by the total person-years at risk (per 100 person-years [PYs]). PWID with a negative HIV test followed by a positive test were defined as HIV-1 seroconverters. The seroconversion time for these subjects was estimated by the midpoint of the seroconversion interval, i.e., the interval between the last negative and the first positive test date, as assessed in the two programs (Supplementary Figure 1). In the process of reporting these new cases to the national HIV surveillance system, we identified a subset of these cases who were already reported with an earlier diagnosis date; in this group of PWID, that date was used as the first positive test date. Based on this additional information, we excluded two participants whose estimated seroconversion time was 
medRxiv preprint doi: https://doi.org/10.1101/2021.06.24.21258830; this version posted June 25, 2021. The copyright holder for this preprint (which was not certified by peer review) is the author/funder, who has granted medRxiv a license to display the preprint in perpetuity.

All rights reserved. No reuse allowed without permission.

during 2012-2013. For participants who remained HIV negative, person-time at risk was calculated as the interval between the first and the last available sample.

\section{Sensitivity analysis of HIV incidence estimation}

As a sensitivity analysis, we calculated HIV incidence using the random-point method, i.e., assuming seroconversion time to be a random date from a uniform distribution bounded by the last negative and first positive test dates ${ }^{10-12}$. To account for the variability of using a random date, multiple iterations were made, and incidence rates were averaged for all iterations.

\section{Statistical analysis}

McNemar's and Wilcoxon rank-sum tests were used to assess changes in socioeconomic factors, injection practices and access to HIV testing and prevention in the prevalence cohort from 2012-2013 to 2018-2020 (as assessed at first participation in each period).

Univariable and multivariable Cox proportional hazard models were used to identify risk factors associated with HIV seroconversion.

To assess differential loss to follow-up, we compared the characteristics of PWID who participated in both programs versus those who participated only in ARISTOTLE 20122013 using t-test, chi-squared test, and Mann-Whitney test, as appropriate. Statistical analyses were done using Stata version 13.1. All p values were two-sided.

\section{Molecular analysis of HIV seroconversions (HIV-1 Subtyping)}

Molecular analysis was performed in 35 out of 57 seroconversions in which HIV-RNA was possible to be amplified. HIV-1 subtypes were determined by the automated HIV1 subtyping tool COMET v0.2 $2^{13}$ and confirmed by phylogenetic analysis. Specifically, 
medRxiv preprint doi: https://doi.org/10.1101/2021.06.24.21258830; this version posted June 25, 2021. The copyright holder for this preprint (which was not certified by peer review) is the author/funder, who has granted medRxiv a license to display the preprint in perpetuity.

All rights reserved. No reuse allowed without permission.

the 35 sequences were analysed phylogenetically along with: i) 247 globally sampled sequences representative of all pure HIV-1 subtypes, sub-subtypes and the majority of circulating recombinant forms (CRFs) collected from the Los Alamos HIV-1 sequence database (http://www.hiv.lanl.gov), and ii) a random collection of 48 sequences from PWID sampled during an outbreak (2011-2015) in Athens, Greece, which fell within the 4 major PWID molecular transmission clusters (MTCs) (subtype A1, subtype B, CRF14_BG, CRF35_AD) $)^{14}$, used as references. Phylogenetic analysis was performed using the approximate maximum likelihood method (GTR+cat) as implemented in FastTree v2.1 program ${ }^{15}$. Furthermore, additional phylogenetic analysis was performed for 3 sequences that did not fall within the 4 PWID MTCs or were not recombinants including partial genomic fragments from the PWID MTCs. Specifically, analysis was performed including a random set of subtype A sequences downloaded from the HV sequence database $(\mathrm{N}=1,500$ sequences $)$ and all available sequences from Greece $(\mathrm{N}=1,992)$ sampled since $1999^{14,16}$. Phylogenetic tree was reconstructed by using the FastTree v2.1 program as described above. The presence of recombination in all sequences which this procedure did not successfully classify was tested by using the RDP4 ${ }^{17}$ and the SimPlot v3.5.1 programs ${ }^{18}$. MEGA version $\mathrm{X}$ was used to align $\begin{array}{lllll}\text { sequences } & \text { (MUSCLE } & \text { algorithm })^{19} & \text { and } & \text { FigTree }\end{array}$ (http://tree.bio.ed.ac.uk/software/figtree/) to display the annotated phylogenetic trees.

\section{Ethical Issues}

The survey protocols and informed consent forms of the two programs were approved by the Institutional Review Boards of: i) the Medical School of the National and Kapodistrian University of Athens and ii) the Hellenic Scientific Society for the Study of AIDS, STDs and Emerging Diseases. Eligible persons were asked to provide written informed consent. The informed consent forms included information about the 
medRxiv preprint doi: https://doi.org/10.1101/2021.06.24.21258830; this version posted June 25,2021 . The copyright holder for this preprint (which was not certified by peer review) is the author/funder, who has granted medRxiv a license to display the preprint in perpetuity.

All rights reserved. No reuse allowed without permission.

program, explained that confidentiality would be protected and that participants were free to withdraw their consent at any point in the process.

\section{Role of the funding sources}

The funding sources had no role in study design; data collection, analysis, or interpretation; in the writing of the report; or in the decision to submit this work for publication. The corresponding author had full access to all the data in the study and had final responsibility for the decision to submit for publication.

\section{Results}

Trends in socioeconomic characteristics, injection practices, access to testing and prevention in repeat participants (2012-2013 and 2018-2020)

Overall, 3,320 and 1,635 PWID were enrolled in ARISTOTLE 2012-2013 and ARISTOTLE HCV-HIV 2018-2020, respectively. In total, 4,274 unique participants were recruited; of those, $681(15.9 \%)$ participated in both programs (prevalence cohort) (Figure 1). Repeat participants were more often male, of Greek origin, with stable accommodation, reporting more often history of imprisonment, and sharing syringes as compared to PWID who did not participate in 2018-2020 (Supplementary Text, Supplementary Table 1).

Out of 681 repeat participants, $81.4 \%$ were men, $94.9 \%$ were Greek and $40.3 \%$ had completed high school or higher (Supplementary Table 1). At their first participation to the 2012-2013 program, the mean (SD) age was 35.0 (7.5) years. The participants were predominantly active PWID (injection in the past 30 days: $78.8 \%-81.7 \%$ in the two periods). 
medRxiv preprint doi: https://doi.org/10.1101/2021.06.24.21258830; this version posted June 25,2021 . The copyright holder for this preprint (which was not certified by peer review) is the author/funder, who has granted medRxiv a license to display the preprint in perpetuity.

All rights reserved. No reuse allowed without permission.

The trends in socioeconomic characteristics, injection practices and access to HIV testing and prevention services over the two periods are depicted in Table 2. PWID in 2018-2020 were more frequently homeless $(25.6 \%$ vs. $16.2 \%, \mathrm{p}<0.001)$, unemployed (91.0\% vs. $78.9 \%, \mathrm{p}<0.001)$ and without health insurance $(79.5 \%$ vs. $61.7 \%, \mathrm{p}<0.001)$, as compared to 2012-2013. There were significant increases in the use of cocaine $(28.1 \%$ vs. $16.6 \%, \mathrm{p}<0.001)$ and speedball $(14.8 \%$ vs. $2.1 \%, \mathrm{p}<0.001)$ as well as a decrease in the use of heroin $(55.3 \%$ vs. $80.7 \%, \mathrm{p}<0.001)$. There was a significant decrease in risky behaviours such as daily injecting drug use (past 12 months: $29.7 \%$ vs. $36.2 \%, \mathrm{p}=0.002$ ) and syringe sharing (about half the time or more in the past 12 months: $23.8 \%$ vs. $40.8 \%, \mathrm{p}<0.001)$.

An increasing percentage of PWID reported being currently in OST (2018-2020 vs. 2012-2013: $30.5 \%$ vs. $13.8 \%, \mathrm{p}<0.001)$; however, there was a decline in the proportion reporting access to free syringes (past 12 months: $45.1 \%$ vs. $51.8 \%, \mathrm{p}=0.005$ ) whereas access to HIV testing remained similar (test in the past 12 months: $49.4 \%$ vs. $50.9 \%$, $\mathrm{p}=0.759)$.

\section{Trends in HIV prevalence (2012-2013 and 2018-2020)}

In the sample of 681 PWID participating in both periods, HIV prevalence increased from $14.2 \%$ (95\% CI: $11.7-17.1)$ in $2012-2013$ to $22.0 \%$ (95\% CI: $19.0-25.3$ ) in $2018-$ 2020 ( $p<0.001)$, i.e., an increase by $54.9 \%$ (Table 3 ). This increase was apparent among both men and women (Table 3 ).

\section{HIV incidence (2014-2020)}

In the cohort of 699 initially seronegative PWID, there were 57 seroconversions identified during follow up: 46 seroconversions in PWID who tested HIV(-) in ARISTOTLE 2012-2013 and were found HIV(+) in the first or second round of 
medRxiv preprint doi: https://doi.org/10.1101/2021.06.24.21258830; this version posted June 25, 2021. The copyright holder for this preprint (which was not certified by peer review) is the author/funder, who has granted medRxiv a license to display the preprint in perpetuity.

All rights reserved. No reuse allowed without permission.

ARISTOTLE HCV-HIV 2018-2020 (43 and 3, respectively) and 11 seroconversions in PWID who tested HIV(-) in the first round of ARISTOTLE HCV-HIV 2018-2020 and were HIV(+) in the second round (Table 1; Supplementary Figure 1). Out of 46 PWID testing negative in 2012-2013 and positive in 2018-2020, 32 were already reported to the national HIV surveillance system with an earlier diagnosis date; that date was used as the first positive date.

The overall HIV incidence (95\% CI) for the period 2014-2020 was 1.94 (1.49-2.51) new cases per 100 PYs. When we considered two-year periods, HIV incidence (95\% CI) was estimated to be 2.10/100 PYs (1.41-3.14) in 2014-2015, 2.04/100 PYs (1.343.10) in 2016-2017 and 1.52/100 PYs (0.84-2.75) in 2018-February 2020 (Table 4).

As a sensitivity analysis, we obtained incidence using an alternative approach for the estimation of the infection date and the findings were similar (Table 4).

\section{Risk factors for HIV seroconversion}

Table 5 presents univariable and multivariable analysis of risk factors for HIV seroconversion. Sociodemographic factors including younger age, lower educational level, and larger size of injection network were identified as independent risk factors for HIV seroconversion in the final model. PWID with lower educational level and larger injecting networks had more than two times higher risk of seroconversion. Concerning injection practices, PWID reporting daily injecting in the past 12 months had 2.45 times higher risk of seroconversion as compared to those injecting less frequently (95\% CI: 1.44-4.15, $\mathrm{p}=0.001)$.

\section{HIV-1 Subtyping}

Molecular analysis was performed in 35 out of 57 seroconversions occurring during 2014-2020. Subtyping analysis showed that $80 \%(n=28)$ of the sequences fell within 
medRxiv preprint doi: https://doi.org/10.1101/2021.06.24.21258830; this version posted June 25, 2021. The copyright holder for this preprint (which was not certified by peer review) is the author/funder, who has granted medRxiv a license to display the preprint in perpetuity.

All rights reserved. No reuse allowed without permission.

the previously identified PWID MTCs in Athens (CRF14_BG: $\mathrm{n}=21,60 \%$; CRF35_AD: $n=4,11.4 \%$; subtype B: $n=2,5.7 \%$; subtype A: $n=1,2.9 \%$ ) (Figure 2A). Unique recombinant forms of the virus were also detected $(n=4,11.4 \%)$ (Figure $2 \mathrm{~A})$. These forms consisted of partial sequences from previously identified PWID MTCs. The remaining sequences $(\mathrm{n}=3,8.6 \%)$ were classified as sub-subtype A6 and found to belong within a single PWID MTC consisting of sub-subtype A6 sequences from PWID diagnosed during 2014-2019 (Figure 2B). Specifically, this cluster included 10 sequences of which 2 were sampled in 2014 and the remaining 8 were sampled later between 2018 and 2020 (Figure 2B). All sequences within A6 cluster were from PWID of Greek ethnicity, apart from three which were found to belong to PWID from Albania, Kazakhstan, and Pakistan. One out of these 3 seroconversions classified in this cluster occurred between September 2018 and November 2019 (last negative and first positive test result, respectively).

\section{Discussion}

In a sample of community-recruited PWID in Athens, Greece, repeatedly tested for HIV in 2012-2013 and 2018-2020, we estimated that HIV prevalence increased by approximately $55 \%$ (from $14.2 \%$ to $22.0 \%$, respectively). Compared to $2012-2013$, in 2018-2020 there was a deterioration of socioeconomic conditions among PWID. Although heroin remained the main substance injected by most participants, there was a shift in the use of cocaine, a substance associated with increased risk of HIV infection and outbreaks ${ }^{20-22}$. Encouragingly, there was a shift to less frequent injecting drug use and an increased access to OST programs. However, access to free syringes decreased, and HIV testing rates remained low (around 50\% tested in the past 12 months). 
medRxiv preprint doi: https://doi.org/10.1101/2021.06.24.21258830; this version posted June 25, 2021. The copyright holder for this preprint (which was not certified by peer review) is the author/funder, who has granted medRxiv a license to display the preprint in perpetuity.

All rights reserved. No reuse allowed without permission.

In a previous analysis of the 2011 outbreak, we estimated that HIV incidence decreased rapidly from 7.8/100 PYs in August-December 2012 to 1.7/100 PYs in AugustDecember $2013^{4}$ (Supplementary Figure 2). In the current study we found that for the period 2014-2020, HIV incidence was 1.94/100 PYs. When this estimate was obtained separately for 2014-2015, 2016-2017 and 2018-February 2020, we observed that HIV incidence remained at stable moderate levels similar to those reached in the second half of 2013.

Phylogenetic analysis showed that the majority of the viral sequences from seroconverters fell within the previously identified PWID molecular transmission clusters in Athens, or they were recombinants with viruses belonging to these clusters ${ }^{14}$. Notably, besides the transmissions originating from the existing outbreak clusters, almost 9\% of PWID seroconversions occurred within a newly expanding A6 cluster. The earliest sequences of this cluster were from 2014 probably introduced from Eastern Europe, where this sub-subtype is endemic. The generation and expansion of a new transmission cluster indicates that the PWID epidemic was fuelled with new strains from former Soviet Union countries and with existing contacts among the active PWID in Athens.

The most important drug-related risk factor for HIV seroconversion was daily injection. This is consistent with the findings concerning the drivers of transmission in the 2011 outbreak in Athens where daily injection was the only drug-related risk factor identified $^{4}$. Younger age was independently associated with increased risk of HIV seroconversion, as in other settings ${ }^{23-26}$. Proposed explanations for this association include less perceived risk among younger PWID and bridging by older PWID to highrisk networks ${ }^{27}$. We also identified lower educational level - a correlate of lower socioeconomic status - to be an independent risk factor, as elsewhere ${ }^{28-31}$. Socio- 
medRxiv preprint doi: https://doi.org/10.1101/2021.06.24.21258830; this version posted June 25, 2021. The copyright holder for this preprint (which was not certified by peer review) is the author/funder, who has granted medRxiv a license to display the preprint in perpetuity.

All rights reserved. No reuse allowed without permission.

economic factors have been proposed to trigger the Athens outbreak in the first place; Greece entered a phase of economic recession in 2008, and this resulted in increased socioeconomic disparities, unemployment, and homelessness among PWID 5 .

An important question is why HIV transmission did not decline further after 2013. In other settings with increased transmission among PWID, such as HaiPhong and Bangkok, HIV incidence declined in the recent years to $<1 / 100 \mathrm{PYs}^{32,33}$. In Athens, as soon as the HIV outbreak was recognized in 2011, several interventions were implemented; NSP coverage increased from 16 syringes/PWID in $2010^{34}$ to 216 in $2013^{35}$ and OST coverage from $21 \%$ in 2010 to $35 \%$ in $2012^{36}$. In addition, ARISTOTLE program reached rapidly a large proportion of PWID (estimated population coverage: $88 \%$ ), offered HIV testing, counselling, and linkage to antiretroviral treatment ${ }^{4,7}$. Data on the cascade of care among people living with HIV in 2013 in Greece confirm that a high proportion of HIV-infected PWID were diagnosed (87\%); however, only $46 \%$ initiated antiretroviral treatment ${ }^{37}$. Following 2013, NSP coverage in Athens was far from optimal with fluctuations over time; from 216 syringes/PWID per year in 2013, it declined to 109 in 2015 and remained low at 164 in $2018^{38}$. In addition, after the completion of ARISTOTLE in 2013, there was no systematic HIV testing of PWID. Our data from repeat participants further confirm that access to free syringes and HIV testing remained suboptimal in both periods. The low levels of testing and NSP coverage in a high HIV prevalence population that has experienced a recent outbreak is alarming. There is a core of PWID not accessing harm reduction programs who are most vulnerable. Ideally, this population should be protected from HIV infection through counselling and education, adequate syringe provision, access to HIV testing and linkage to antiretroviral treatment implemented through community-based programs specifically designed to address their needs. From 
medRxiv preprint doi: https://doi.org/10.1101/2021.06.24.21258830; this version posted June 25, 2021. The copyright holder for this preprint (which was not certified by peer review) is the author/funder, who has granted medRxiv a license to display the preprint in perpetuity.

All rights reserved. No reuse allowed without permission.

an HIV surveillance point of view, these results provide empirical evidence why prevalence studies cannot adequately capture this core population and provide evidence that cohort studies with active enrollment are necessary as surveillance tools.

Our analysis has some limitations. First, estimates of HIV prevalence in 2012-2013 and 2018-2020 were based on a sample of PWID participating in both programs. This is a convenience sample of people continuing drug use over these years representing a highrisk population injecting drugs for prolonged time. We do not suggest that the estimated prevalence for 2018-2020 reflects the prevalence in the total PWID population in that period; rather, we aimed to provide an estimate of the prevalence among those remaining active PWID. Second, concerning the estimation of HIV incidence, there was no regular follow-up for 46 seroconversions with a negative test result in 20122013 identified positive in 2018-2020. We used the midpoint method which clusters the imputed seroconversion dates at the middle of the observation period. If these infection events took place near the outbreak period, then under the midpoint approach the time at risk would be overestimated and HIV incidence would be underestimated. To deal with this problem, for 30 out of 46 of these cases who were already reported to the national HIV surveillance system with an earlier diagnosis date, we used that date as a putative first positive date. In addition, we used as sensitivity analysis the randompoint method that has been proposed for low testing rates in cohorts ${ }^{10}$ and the results were similar. Our estimate for the third period (2018-February 2020) including 11 seroconversions, does not suffer from this limitation as most seroconversions were observed in a short observation period.

Despite the large and rapid decline in HIV incidence during 2012-2013, there were indications of ongoing transmission; molecular analysis conducted on HIV-1 sequences from PWID suggested that endemic transmission was still occurring at the end of $2013^{39}$ 
medRxiv preprint doi: https://doi.org/10.1101/2021.06.24.21258830; this version posted June 25, 2021. The copyright holder for this preprint (which was not certified by peer review) is the author/funder, who has granted medRxiv a license to display the preprint in perpetuity.

All rights reserved. No reuse allowed without permission.

and the number of newly diagnosed cases reported to the national HIV surveillance system after 2013 never returned to the pre-outbreak levels. Our analysis confirms the ongoing transmission in the population; moreover, we identified a new cluster that probably originated from former Soviet Union countries, a finding which suggests expansion of transmission among newly established networks of PWID. It should be noted that ARISTOTLE HIV-HCV was prematurely discontinued in February 2020 due to the COVID-19 pandemic. Preliminary data collection in Athens and sites with recent HIV outbreaks suggests that COVID-19 has severely impacted HIV prevention services for PWID, possibly resulting in an increased risk for HIV transmission among PWID $^{40}$. The ongoing HIV transmission among PWID in Athens provides empirical evidence that the current level of prevention and treatment services is inadequate to control the epidemic and results in the expansion of the pool of infected PWID and in increase of HIV prevalence. Re-evaluation of prevention and treatment programs is urgently needed. 
medRxiv preprint doi: https://doi.org/10.1101/2021.06.24.21258830; this version posted June 25,2021 . The copyright holder for this preprint (which was not certified by peer review) is the author/funder, who has granted medRxiv a license to display the preprint in perpetuity.

\section{Acknowledgements}

We would like to thank the participants of the two programs. We would also like to acknowledge the contribution of the staff of ARISTOTLE and ARISTOTLE HCV-HIV programs:

C. Bagos, M. Esmaili, H. Malekian, E. Karamanou, F. Leobilla, C. Mourtezou, E. Sidrou, M. Zigouritsas, M. Dimitropoulou, N. Kagelari, M. Michail, S. Papadopoulos, and A. Vlahos (ARISTOTLE staff)

M. Dragasaki, K. Kourousi, G. Antoniou, H. Malekian, P. Tzimis, N. Fitsialos, L. Polychronopoulou, E. Kokolesis, P. Axaopoulos, and K. Kontsantinou (ARISTOTLE HCV-HIV staff)

ARISTOTLE HCV-HIV was conducted under the auspices of a) the City of Athens and b) the Organization Against Drugs (OKANA). We would like to acknowledge the support of the following persons in the implementation of this program: the Mayor of the City of Athens (K. Bakoyannis), K. Kokkolis and A. Theocharis (Organisation Against Drugs) and A. Fotiou (Greek National Monitoring \& Documentation Center for Drugs \& Drug Addiction).

\section{Author contributions}

AH designed ARISTOTLE program. AH and VS designed ARISTOLE HCV-HIV program. AH and VS acquired funding. AH and VS supervised the programs. TA and SC participated in data collection. SR and VS had access and analysed the data. EF contributed to data analysis. DParaskevis, EGK and AB analysed the molecular data. EH, MPylli, CT and DParaskeva contributed to data collection on HIV seroconversions 
medRxiv preprint doi: https://doi.org/10.1101/2021.06.24.21258830; this version posted June 25, 2021. The copyright holder for this preprint (which was not certified by peer review) is the author/funder, who has granted medRxiv a license to display the preprint in perpetuity.

All rights reserved. No reuse allowed without permission.

from the national HIV registry. SR, VS, and AH did the initial literature search. SR, VS, AH, DP and EGK wrote the first draft of the manuscript. SR, DParaskevis, MPsichogiou, EGK, EF, TA, SC, MPapadopoulou, IDP, MM, EH, MPylli, CT, DParaskeva, AB, GK, AH, and VS interpreted the findings and contributed to critical review and development of the final manuscript.

\section{Financial support statement}

This study was supported as follows: i) ARISTOTLE 2012-2013 program was funded by the European Union with Greek national funds through the National Strategic Reference Framework 2007-2013 (MIS 365008), ii) ARISTOTLE HCV-HIV program was supported by Gilead Sciences, AbbVie, and MSD. Both programs were jointly funded by the Hellenic Scientific Society for the Study of AIDS STDs and Emerging Diseases.

Additional support was provided by the following grants: i) European Union and Greek national funds through the Operational Program "Human Resources Development, Education and Lifelong Learning" (NSRF 2014-2020), under the call "Supporting Researchers with an Emphasis on Young Researchers - Cycle B" (MIS: 16508), and ii) Asklepios Program (Gilead Hellas).

\section{Conflict of interest statement}

VS has received a grant by Gilead Sciences and Abbvie for the submitted work. She has served as a lecturer for Gilead, Abbvie, and Janssen. 
medRxiv preprint doi: https://doi.org/10.1101/2021.06.24.21258830; this version posted June 25, 2021. The copyright holder for this preprint (which was not certified by peer review) is the author/funder, who has granted medRxiv a license to display the preprint in perpetuity.

All rights reserved. No reuse allowed without permission.

DParaskevis has received grants from Gilead Sciences and GSK and participated in advisory boards of Gilead Sciences, GSK and MSD

MPsichogiou has received a grant by Gilead Sciences, served as a lecturer for Gilead, Abbvie and MSD and participated in advisory boards for Gilead, Abbvie and MSD

GK has received a grant by Gilead Sciences.

$\mathrm{AH}$ has participated in advisory boards for Gilead, AbbVie, BMS and received unrestricted grants: from AbbVie, BMS, Gilead, MSD, Novartis. He is Co-Chair of Hepatitis B \& C Public Policy Association funded by AbbVie, Gilead, and MSD.

SR, EGK, EF, TA, SC, MPapadopoulou, IDP, MM, EH, MPylli, CT, DParaskeva, AB, have nothing to disclose.

\section{Data sharing}

Data are not available for sharing. 
medRxiv preprint doi: https://doi.org/10.1101/2021.06.24.21258830; this version posted June 25, 2021. The copyright holder for this preprint (which was not certified by peer review) is the author/funder, who has granted medRxiv a license to display the preprint in perpetuity.

\section{References}

1. Degenhardt L, Peacock A, Colledge S, et al. Global prevalence of injecting drug use and sociodemographic characteristics and prevalence of HIV, HBV, and HCV in people who inject drugs: a multistage systematic review. The Lancet Global health 2017; 5(12): e1192-e207.

2. Des Jarlais DC, Kerr T, Carrieri P, Feelemyer J, Arasteh K. HIV infection among persons who inject drugs: ending old epidemics and addressing new outbreaks. AIDS 2016; 30(6): 815-26.

3. Des Jarlais DC, Sypsa V, Feelemyer J, et al. HIV outbreaks among people who inject drugs in Europe, North America, and Israel. Lancet HIV 2020; 7(6): e434-e42.

4. Sypsa V, Psichogiou M, Paraskevis D, et al. Rapid Decline in HIV Incidence Among Persons Who Inject Drugs During a Fast-Track Combination Prevention Program After an HIV Outbreak in Athens. The Journal of infectious diseases 2017; 215(10): 1496-505.

5. Paraskevis D, Nikolopoulos G, Fotiou A, et al. Economic recession and emergence of an HIV-1 outbreak among drug injectors in Athens metropolitan area: a longitudinal study. PloS one 2013; 8(11): e78941.

6. Malliori M, Golna C, Souliotis K, Hatzakis A. Financial crisis, austerity, and health in Europe. Lancet 2013; 382(9890): 392.

7. Hatzakis A, Sypsa V, Paraskevis D, et al. Design and baseline findings of a large-scale rapid response to an HIV outbreak in people who inject drugs in Athens, Greece: the ARISTOTLE programme. Addiction 2015; 110(9): 1453-67.

8. National Public Health Organization. HIV/AIDS Surveillance Report in Greece, 31-12-2019 (Issue 34). Athens 2020. Also available at: https://eody.gov.g.

9. Heckathorn D. Respondent-driven sampling: a new approach to the study of hidden populations. Soc Probl 1997; 44: 174---99.

10. Vandormael A, Dobra A, Barnighausen T, de Oliveira T, Tanser F. Incidence rate estimation, periodic testing and the limitations of the mid-point imputation approach. Int J Epidemiol 2018; 47(1): 236-45.

11. Kasamba I, Nash S, Seeley J, Weiss HA. HIV incidence among women at high risk of HIV infection attending a dedicated clinic in Kampala, Uganda: 2008-2017. Sexually transmitted diseases 2019; 46(6): 407-15. 
medRxiv preprint doi: https://doi.org/10.1101/2021.06.24.21258830; this version posted June 25,2021 . The copyright holder for this preprint (which was not certified by peer review) is the author/funder, who has granted medRxiv a license to display the preprint in perpetuity.

All rights reserved. No reuse allowed without permission.

12. Martin M, Vanichseni S, Sangkum U, et al. HIV Incidence and Risk Behaviours of People Who Inject Drugs in Bangkok, 1995-2012. EClinicalMedicine 2019; 9: 4451.

13. Struck D, Lawyer G, Ternes A-M, Schmit J-C, Bercoff DP. COMET: adaptive context-based modeling for ultrafast HIV-1 subtype identification. Nucleic acids research 2014; 42(18): e144-e.

14. Kostaki E, Magiorkinis G, Psichogiou M, et al. Detailed molecular surveillance of the HIV-1 outbreak among people who inject drugs (PWID) in Athens during a period of four years. Current HIV research 2017; 15(6): 396-404.

15. Price MN, Dehal PS, Arkin AP. FastTree 2-approximately maximumlikelihood trees for large alignments. PloS one 2010; 5(3): e9490.

16. Paraskevis D, Kostaki E, Magiorkinis G, et al. Prevalence of drug resistance among HIV-1 treatment-naive patients in Greece during 2003-2015: Transmitted drug resistance is due to onward transmissions. Infection, genetics and evolution : journal of molecular epidemiology and evolutionary genetics in infectious diseases 2017; 54: 183 91.

17. Martin DP, Lemey P, Lott M, Moulton V, Posada D, Lefeuvre P. RDP3: a flexible and fast computer program for analyzing recombination. Bioinformatics 2010; 26(19): 2462-3.

18. Lole KS, Bollinger RC, Paranjape RS, et al. Full-length human immunodeficiency virus type 1 genomes from subtype $\mathrm{C}$-infected seroconverters in India, with evidence of intersubtype recombination. Journal of virology 1999; 73(1): $152-60$

19. Kumar S, Stecher G, Li M, Knyaz C, Tamura K. MEGA X: molecular evolutionary genetics analysis across computing platforms. Molecular biology and evolution 2018; 35(6): 1547-9.

20. McAuley A, Palmateer NE, Goldberg DJ, et al. Re-emergence of HIV related to injecting drug use despite a comprehensive harm reduction environment: a crosssectional analysis. Lancet HIV 2019; 6(5): e315-e24.

21. Arendt V, Guillorit L, Origer A, et al. Injection of cocaine is associated with a recent HIV outbreak in people who inject drugs in Luxembourg. PloS one 2019; 14(5): $\mathrm{e} 0215570$.

22. Tyndall MW, Currie S, Spittal P, et al. Intensive injection cocaine use as the primary risk factor in the Vancouver HIV-1 epidemic. AIDS 2003; 17(6): 887-93. 
medRxiv preprint doi: https://doi.org/10.1101/2021.06.24.21258830; this version posted June 25,2021 . The copyright holder for this preprint (which was not certified by peer review) is the author/funder, who has granted medRxiv a license to display the preprint in perpetuity.

23. Strathdee SA, Galai N, Safaiean M, et al. Sex differences in risk factors for hiv seroconversion among injection drug users: a 10-year perspective. Arch Intern Med 2001; 161(10): 1281-8.

24. Sharifi H, Mirzazadeh A, Shokoohi M, et al. Estimation of HIV incidence and its trend in three key populations in Iran. PloS one 2018; 13(11): e0207681.

25. Ganapathi L, McFall AM, Srikrishnan AK, et al. Young people who inject drugs in India have high HIV incidence and behavioural risk: a cross-sectional study. $J$ Int AIDS Soc 2019; 22(5): e25287.

26. Scheim AI, Nosova E, Knight R, Hayashi K, Kerr T. HIV Incidence Among Men Who Have Sex with Men and Inject Drugs in a Canadian Setting. AIDS Behav 2018; 22(12): 3957-61.

27. De P, Cox J, Boivin JF, Platt RW, Jolly AM. The importance of social networks in their association to drug equipment sharing among injection drug users: a review. Addiction 2007; 102(11): 1730-9.

28. Jolley E, Rhodes T, Platt L, et al. HIV among people who inject drugs in Central and Eastern Europe and Central Asia: a systematic review with implications for policy. BMJ Open 2012; 2(5).

29. Richardson L, Mammel M, Milloy MJ, Hayashi K. Employment Cessation, Long Term Labour Market Engagement and HIV Infection Risk Among People Who Inject Drugs in an Urban Canadian Setting. AIDS Behav 2019; 23(12): 3267-76.

30. Czerwinski M, McNutt LA, DeHovitz JA, Zielinski A, Rosinska M. Refining HIV risk: the modifying effects of youth, gender and education among people who inject drugs in Poland. PloS one 2013; 8(7): e68018.

31. Mburu G, Chhoun P, Chann N, Tuot S, Mun P, Yi S. Prevalence and risk factors of HIV infection among people who inject drugs in Cambodia: findings from a national survey. Subst Abuse Treat Prev Policy 2019; 14(1): 42.

32. Martin M, Vanichseni S, Sangkum U, et al. HIV Incidence and Risk Behaviours of People Who Inject Drugs in Bangkok, 1995-2012. EClinicalMedicine 2019; 9: 4451.

33. Des Jarlais DC, Huong DT, Oanh KTH, et al. Ending an HIV epidemic among persons who inject drugs in a middle-income country: extremely low HIV incidence among persons who inject drugs in Hai Phong, Viet Nam. AIDS 2020; 34(15): 230511 . 
medRxiv preprint doi: https://doi.org/10.1101/2021.06.24.21258830; this version posted June 25, 2021. The copyright holder for this preprint (which was not certified by peer review) is the author/funder, who has granted medRxiv a license to display the preprint in perpetuity.

All rights reserved. No reuse allowed without permission.

34. Greek Documentation and Monitoring Centre for Drugs. Annual Report on the State of Drugs and Alcohol in Greece (2012) [in Greek].

35. Greek Reitox National Focal Point. 2014 National Report (2013 data) to the EMCDDA. GREECE New Development, Trends.

36. Fotiou A, Micha K, Terzidou M, Malliori M, Paraskevis D, Hatzakis A. HIV outbreak in injecting drug users in Greece: An updated brief report for the EMCDDA on the recent outbreak of HIV infections among drug injectors in Greece. 15 November 2012. Athens: REITOX Focal Point of the EMCDDA-Greece 2012. Available from: http://www.emcdda.europa.eu/publications/ad-hoc/2012/greece-hiv-updat.

37. Vourli G, Nikolopoulos G, Paparizos V, et al. HIV cascade of care in Greece: Useful insights from additional stages. PloS one 2018; 13(11): e0207355.

38. National Documentation and Information Centre on Drugs and Drug Addiction. Annual Report on the State of Drugs and Alcohol in Greece 2019. Athens 2020.

39. Paraskevis D, Paraschiv S, Sypsa V, et al. Enhanced HIV-1 surveillance using molecular epidemiology to study and monitor HIV-1 outbreaks among intravenous drug users (IDUs) in Athens and Bucharest. Infection, genetics and evolution : journal of molecular epidemiology and evolutionary genetics in infectious diseases 2015; 35: $109-21$.

40. Wiessing L, Sypsa V, Arendt V, et al. Impact of COVID-19 on services for people who inject drugs in sites with recent HIV outbreaks in Europe, North America and Israel. 23d International AIDS Conference; 2020; 2020. 
medRxiv preprint doi: https://doi.org/10.1101/2021.06.24.21258830; this version posted June 25, 2021. The copyright holder for this preprint (which was not certified by peer review) is the author/funder, who has granted medRxiv a license to display the preprint in perpetuity.

All rights reserved. No reuse allowed without permission.

Figure 1. People who inject drugs participating in ARISTOTLE (2012-2013) and ARISTOTLE HCV-HIV (2018-2020) included in the analysis of HIV prevalence and incidence in Athens, Greece.

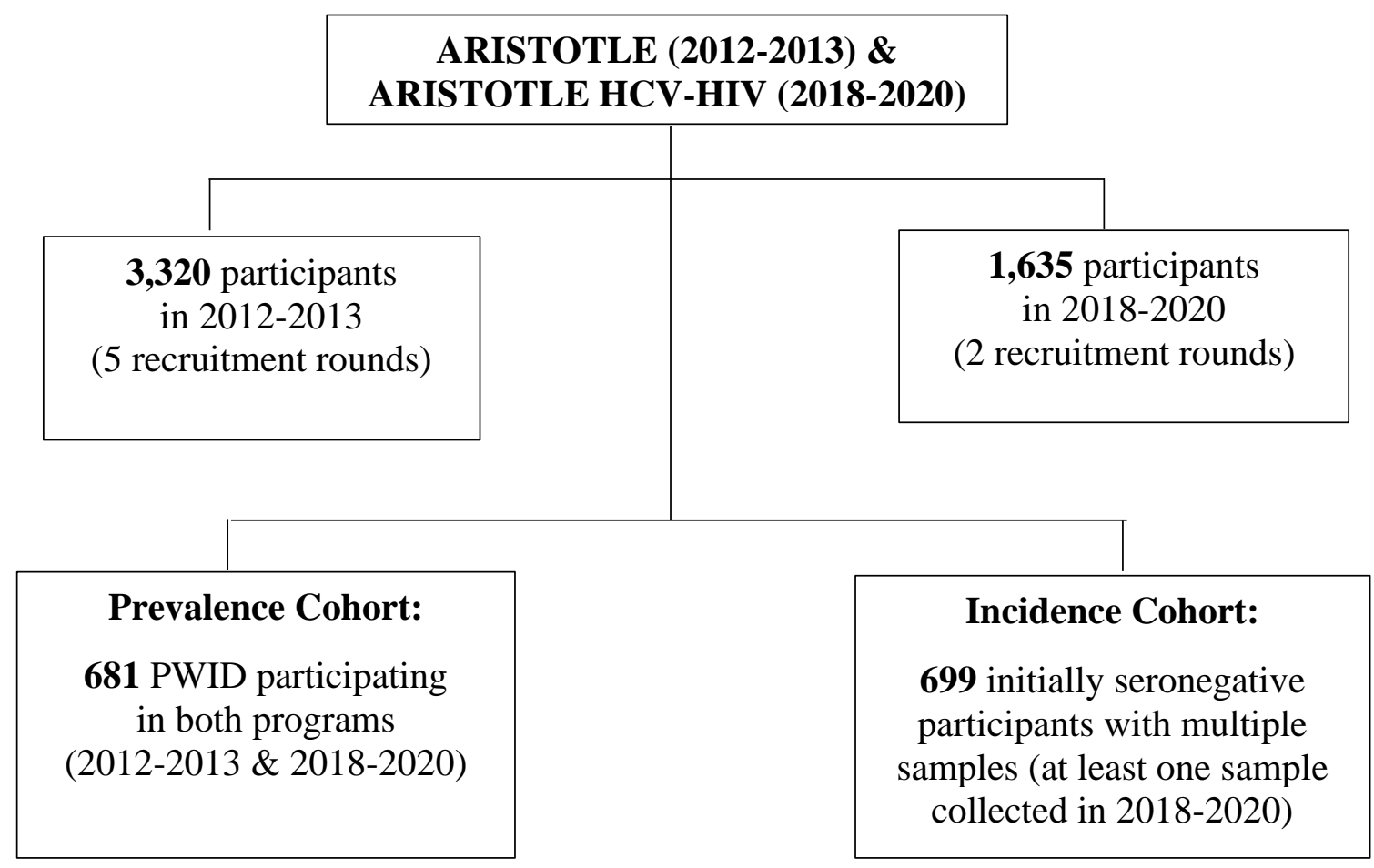


medRxiv preprint doi: https://doi.org/10.1101/2021.06.24.21258830; this version posted June 25, 2021. The copyright holder for this preprint (which was not certified by peer review) is the author/funder, who has granted medRxiv a license to display the preprint in perpetuity.

All rights reserved. No reuse allowed without permission.

Figure 2A. Unrooted phylogenetic tree of the HIV-1 sequences under study (seroconversions; red color) and reference sequences (black and green colors) inferred by using an approximately maximum-likelihood method as implemented in FastTree2 program. Representative sequences of pure HIV-1 subtypes, sub-subtypes and circulating recombinant forms collected from the Los Alamos HIV-1 sequence database (marked in black) and sequences from the four major molecular transmission clusters among people who inject drugs in Athens, Greece, (marked in green) were used as references. For the sake of clarity, a subset of the reference sequences was used. The names of subtypes, sub-subtypes, circulating recombinant forms, and unique recombinant forms are shown on the top of the corresponding clades. Abbreviations: CRF, circulating recombinant form; MTC, molecular transmission cluster; PWID, people who inject drugs; URF, unique recombinant form.

Figure 2B. Unrooted phylogenetic tree of HIV-1 subtype A sequences from Athens, Greece, and other geographic regions around the world. For the sake of clarity, a subset of sequences was used. Red circles indicate seroconversions in Athens while green and black circles indicate sequences sampled in Athens and elsewhere, respectively. An enlarged view of the tree shows the sub-subtype A6 molecular transmission cluster consisted of 10 sequences from people who inject drugs sampled in Athens during 2014-2019. Asterisks indicate sequences from non-Greek people who inject drugs. The phylogenetic tree was inferred by using an approximately maximum-likelihood method as implemented in FastTree2 program. 
medRxiv preprint doi: https://doi.org/10.1101/2021.06.24.21258830; this version posted June 25, 2021. The copyright holder for this preprint (which was not certified by peer review) is the author/funder, who has granted medRxiv a license to display the preprint in perpetuity.

All rights reserved. No reuse allowed without permission.

\section{A.}

Seroconversions (Athens)

References (Athenian PWID MTCs)

References (Globally sampled)

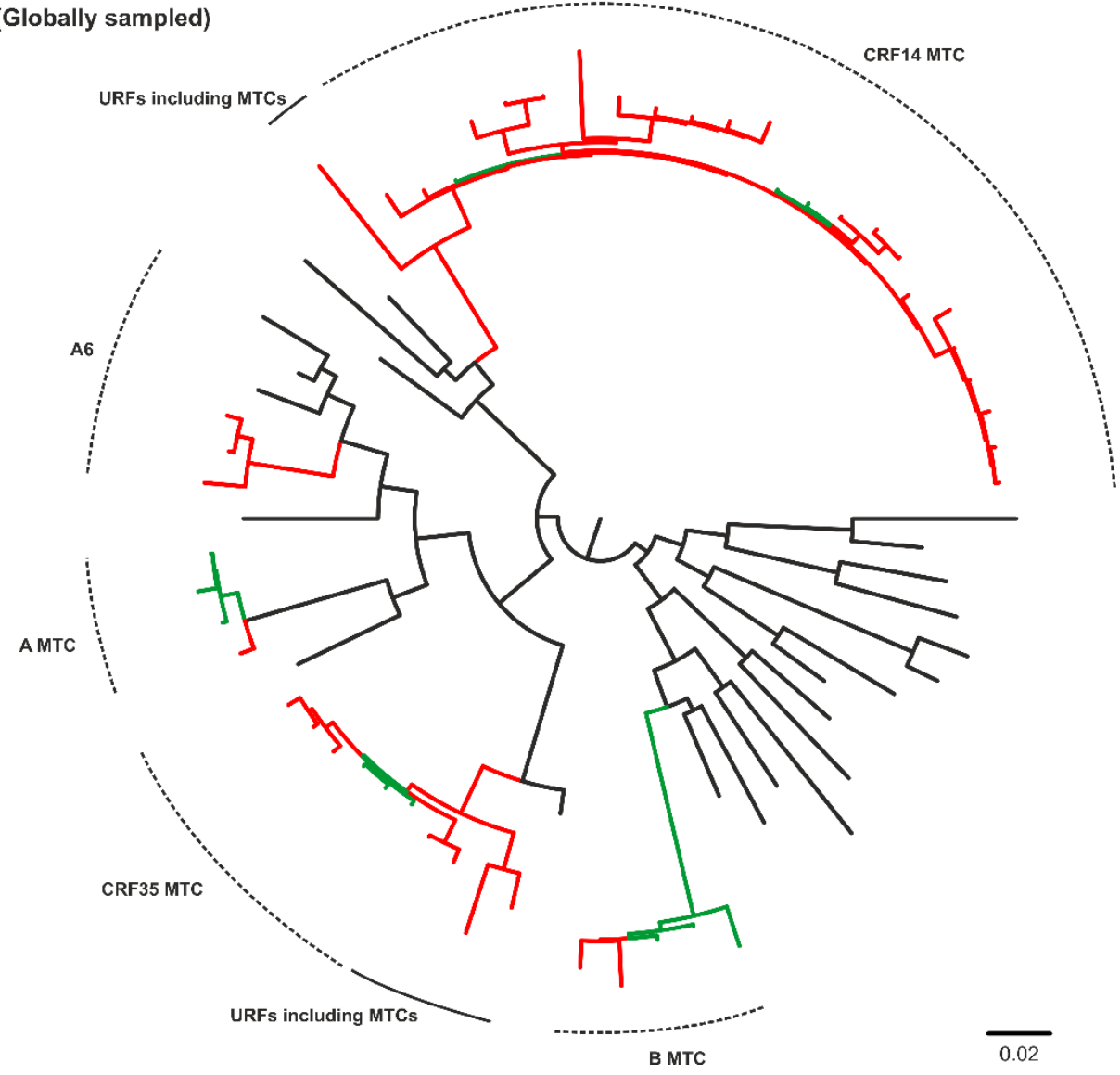


medRxiv preprint doi: https://doi.org/10.1101/2021.06.24.21258830; this version posted June 25, 2021. The copyright holder for this preprint (which was not certified by peer review) is the author/funder, who has granted medRxiv a license to display the preprint in perpetuity.

$2 B$.

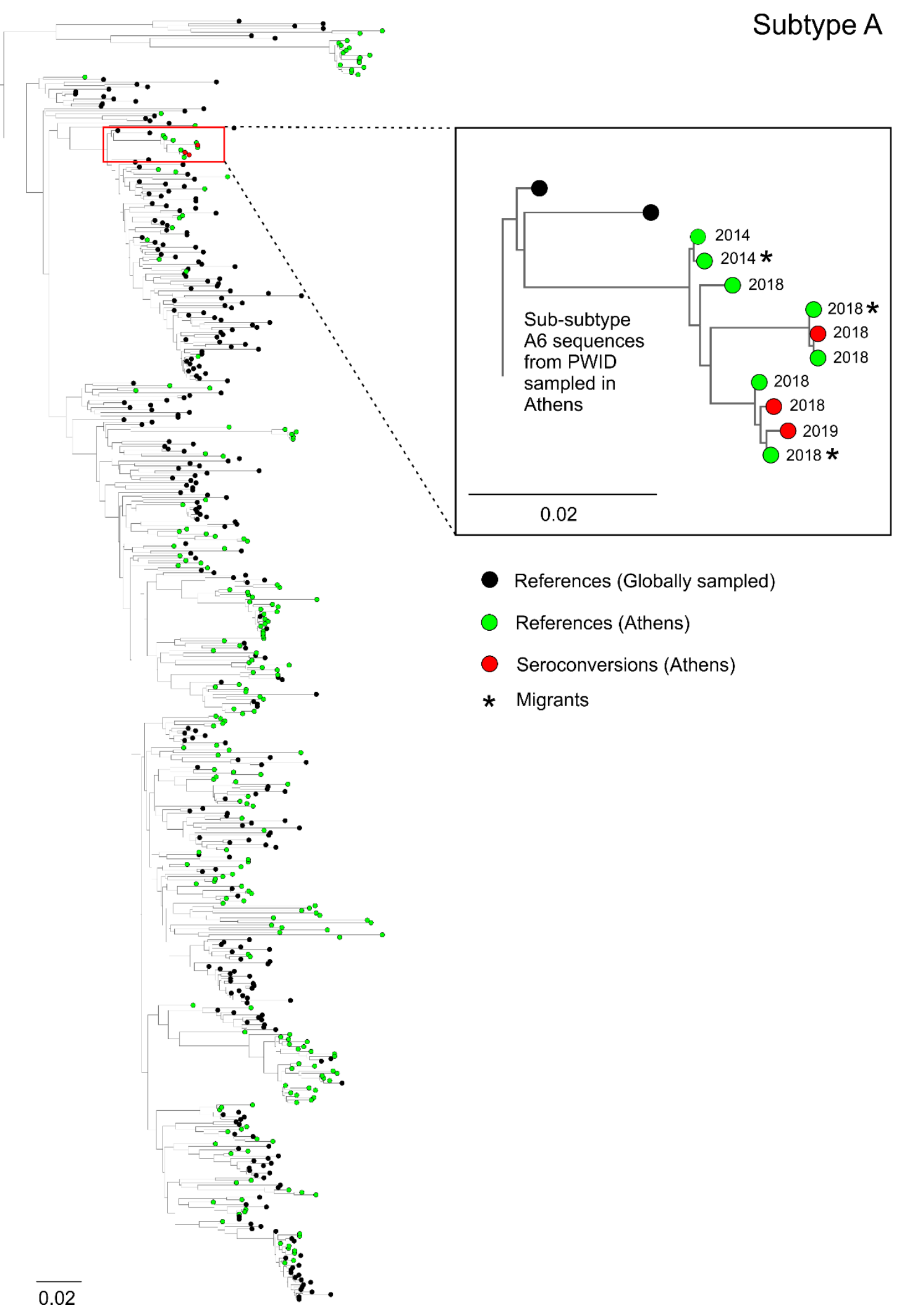


medRxiv preprint doi: https://doi.org/10.1101/2021.06.24.21258830; this version posted June 25, 2021. The copyright holder for this preprint (which was not certified by peer review) is the author/funder, who has granted medRxiv a license to display the preprint in perpetuity.

All rights reserved. No reuse allowed without permission.

Table 1. Distribution of HIV seroconversions observed during 2014-2020 in a cohort of 699 seronegative community-recruited people who inject drugs in Athens, Greece.

\begin{tabular}{|c|c|c|c|c|}
\hline ARISTOTLE & ARISTOTI & E HCV-HIV & & \\
\hline 2012-2013 & 2018 & 2020 & & \\
\hline $\begin{array}{c}\text { Last } \\
\text { participation }\end{array}$ & $\begin{array}{c}\text { Round A } \\
\text { April 2018 - } \\
\text { February } 2019\end{array}$ & $\begin{array}{c}\text { Round B } \\
\text { August 2019 - } \\
\text { February } 2020\end{array}$ & $\begin{array}{c}\text { Number of } \\
\text { PWID at risk }\end{array}$ & $\begin{array}{c}\text { Number of } \\
\text { Seroconversions }\end{array}$ \\
\hline HIV $(-)$ & $\mathrm{HIV}(+)$ & & 343 & 43 \\
\hline HIV $(-)$ & & $\mathrm{HIV}(+)$ & 92 & 3 \\
\hline \multirow[t]{3}{*}{ HIV $(-)$} & HIV $(-)$ & $\mathrm{HIV}(+)$ & 147 & 5 \\
\hline & HIV $(-)$ & $\mathrm{HIV}(+)$ & 117 & 6 \\
\hline & Total & & 699 & 57 \\
\hline
\end{tabular}


medRxiv preprint doi: https://doi.org/10.1101/2021.06.24.21258830; this version posted June 25, 2021. The copyright holder for this preprint (which was not certified by peer review) is the author/funder, who has granted medRxiv a license to display the preprint in perpetuity.

All rights reserved. No reuse allowed without permission.

Table 2. Trends in socio-economic and network characteristics, drug use behaviour and access to HIV prevention services in people who inject drugs participating in both ARISTOTLE (2012-2013) and ARISTOTLE HIV-HCV (2018-2020) programs $(\mathrm{N}=681)$ (as assessed in their first visit to each program).

2012-2013

2018-2020

p-value

\section{A. Socio-economic and network characteristics}

Homeless now, n (\%)

$110(16.2) \quad 174(25.6) \quad<0.001$

Unemployment, n (\%)

$535(78.9) \quad 619(91.0) \quad<0.001$

Without health insurance, $\mathrm{n}(\%)$

$518(61.7) \quad 538(79.5) \quad<0.001$

History of imprisonment (past 12 months), n (\%)

$148(21.9)$

$87(12.8)$

$<0.001$

Size of participant's injection network, median

(25th, 75th)

$$
20(10,50) \quad 20(10,50) \quad 0.024
$$

\section{B. Injecting drug use behaviour}

Main substance of use (past 12 months), n (\%)

$\begin{array}{llll}\text { Heroin/Thai } & 549(80.7) & 362(55.3) & <0.001 \\ \text { Cocaine } & 113(16.6) & 184(28.1) & <0.001 \\ \text { Speedball } & 14(2.1) & 97(14.8) & <0.001 \\ \text { Other } & 4(0.6) & 12(1.8) & 0.057\end{array}$

Injecting drug use (past 30 days), n (\%)

$554(81.7) \quad 536(78.8)$

0.176

Daily injecting drug use (past 12 months), $n$

$246(36.2) \quad 194(29.7) \quad 0.002$

Receptive syringe-sharing about half the time or

$277(40.8) \quad 156(23.8) \quad<0.001$

more (past 12 months), n (\%) 
medRxiv preprint doi: https://doi.org/10.1101/2021.06.24.21258830; this version posted June 25, 2021. The copyright holder for this preprint (which was not certified by peer review) is the author/funder, who has granted medRxiv a license to display the preprint in perpetuity.

All rights reserved. No reuse allowed without permission.

Use drugs divided with a syringe that someone

else had already injected with about half the time

$60(8.9)$

$36(6.2)$

0.050

or more (past 12 months), n (\%)

\section{Access to testing, drug treatment and prevention}

Currently in opioid substitution treatment, n (\%) $93(13.8) \quad 207(30.5) \quad<0.001$

\begin{tabular}{llll}
\hline Received free syringes (past 12 months), $\mathrm{n}(\%)$ & $352(51.8)$ & 307 (45.1) & 0.005
\end{tabular}

\begin{tabular}{llll}
\hline Tested for HIV (past 12 months), n (\%) & $344(50.9)$ & $310(49.4)$ & 0.759
\end{tabular} 
medRxiv preprint doi: https://doi.org/10.1101/2021.06.24.21258830; this version posted June 25, 2021. The copyright holder for this preprint (which was not certified by peer review) is the author/funder, who has granted medRxiv a license to display the preprint in perpetuity.

All rights reserved. No reuse allowed without permission.

Table 3. Trends in HIV prevalence in people who inject drugs participating in both

ARISTOTLE 2012-2013 and ARISTOTLE HCV-HIV 2018-2020 programs in Athens,

Greece $(\mathrm{N}=681)$.

\begin{tabular}{|c|c|c|c|c|c|c|}
\hline & & & $012-2013$ & & 018-2020 & p-value ${ }^{1}$ \\
\hline & & HIV(+) & $\%(95 \% \mathrm{CI})$ & HIV(+) & $\%(95 \% \mathrm{CI})$ & \\
\hline Total & 681 & 97 & $14.2(11.7-17.1)$ & 150 & $22.0(19.0-25.3)$ & $<0.001$ \\
\hline Male & 554 & 82 & $14.8(11.9-18.0)$ & 126 & $22.7(19.3-26.5)$ & $<0.001$ \\
\hline Female & 127 & 15 & $11.8(6.8-18.7)$ & 24 & $18.9(12.5-26.8)$ & 0.004 \\
\hline
\end{tabular}

${ }^{1}$ McNemar's test. Abbreviation: CI, confidence interval 
medRxiv preprint doi: https://doi.org/10.1101/2021.06.24.21258830; this version posted June 25,2021 . The copyright holder for this preprint (which was not certified by peer review) is the author/funder, who has granted medRxiv a license to display the preprint in perpetuity.

All rights reserved. No reuse allowed without permission.

Table 4. HIV incidence among people who inject drugs in Athens, Greece (N=699 initially seronegative people who inject drugs with multiple samples and at least one sample collected in 2018-2020). The seroconversion date was estimated using the midpoint or the random-point approach. In the random-point approach, estimations were obtained from the average of multiple iterations.

\section{Midpoint}

Random-point

Seroconversions, Time at risk HIV incidence/100 Pys HIV incidence/100 Pys

No. $\quad($ years $) \quad(95 \% \mathrm{CI})$

$(95 \% \mathrm{CI})$

\section{Overall}

$2014-2020$

57

2,943

$1.94(1.49-2.51)$

$1.94(1.49-2.51)$

\section{By period}

$2014-2015$

24

1,142

$2.10(1.41-3.14)$

$2.58(1.80-3.71)$

$2016-2017$

22

1,078

$2.04(1.34-3.10)$

$1.35(0.81-2.24)$

2018 - February $2020^{1}$

11

724

$1.52(0.84-2.75)$

$1.82(1.06-3.12)$

${ }^{1}$ The end of ARISTOTLE HCV-HIV program.

Abbreviations: PYs, person-years, CI, confidence interval 
medRxiv preprint doi: https://doi.org/10.1101/2021.06.24.21258830; this version posted June 25, 2021. The copyright holder for this preprint (which was not certified by peer review) is the author/funder, who has granted medRxiv a license to display the preprint in perpetuity.

All rights reserved. No reuse allowed without permission.

Table 5. Predictors of HIV seroconversion in people who inject drugs, Athens, Greece $(\mathrm{N}=699)$.

\section{Variable}

\section{Crude HR}

p-

Adjusted HR

p-

A. Socio-demographic and network characteristics

$\begin{array}{lllll}\text { Age (years) } & 0.93(0.90-0.97) & <0.001 & 0.93(0.90-0.97) & <0.001\end{array}$

\section{Gender}

Female

(95\% CI)

value $\quad(95 \% \mathrm{CI})$

value
Male
$1.16(0.57-2.37)$
0.675

\section{Country of origin}

Greece

1

Other

$0.78(0.25-2.51) \quad 0.682$

\section{Highest completed level of education}

$\begin{array}{lllll}\text { High school or higher level } & 1 & & & \\ \text { Middle/secondary school or below } & 2.79(1.47-5.28) & 0.002 & 2.33(1.22-4.43) & 0.010\end{array}$

Homeless (in the past 12 months)

$\begin{array}{lll}\text { No } & 1 & \\ \text { Yes } & 1.18(0.67-2.07) & 0.575\end{array}$

Currently health insurance

Yes

1

No $\quad 1.24(0.71-2.17) \quad 0.450$

Unemployed or unable to work for health

reasons

$\begin{array}{lll}\text { Yes } & 1 & \\ \text { No } & 1.63(0.88-3.03) & 0.120\end{array}$

History of imprisonment (in the past 12

months)

$\begin{array}{lll}\text { No } & 1 & \\ \text { Yes } & 1.24(0.62-2.45) & 0.542\end{array}$

Size of participant's network

$\leq 10$ 
medRxiv preprint doi: https://doi.org/10.1101/2021.06.24.21258830; this version posted June 25, 2021. The copyright holder for this preprint (which was not certified by peer review) is the author/funder, who has granted medRxiv a license to display the preprint in perpetuity.

\section{B. Injecting drug use behaviour}

\section{Main substance of use (in the past 12}

months)

$\begin{array}{lll}\text { Cocaine } & 1 & \\ \text { Heroin/Thai } & 1.25(0.65-2.42) & 0.501 \\ \text { Other } & 0.35(0.45-2.72) & 0.316\end{array}$

Injecting drug use in the past 30 days

\begin{tabular}{lll}
\hline $\begin{array}{lll}\text { No } \\
\text { Yes }\end{array}$ & 1 & \\
\hline $\begin{array}{l}\text { Duration of injecting drug use (years), } \\
\text { median (25th, 75th) }\end{array}$ & $0.98(1.12-7.07)$ & 0.027 \\
\hline
\end{tabular}

Daily injecting drug use (past 12 months)

$\begin{array}{lllll}\text { No } & 1 & 1 & \\ \text { Yes } & 3.02(1.79-5.07) & <0.001 & 2.45(1.44-4.15) & 0.001\end{array}$

\section{Receptive syringe-sharing (past 12 months)}

Never or rarely

About half the time or more

$1.89(0.76-4.74) \quad 0.174$

\section{Use drugs divided with a syringe that}

someone else had already injected with

(past 12 months)

Never or rarely

1

About half the time or more

$2.68(1.15-6.24) \quad 0.022$

Abbreviations: HR, hazard ratio; $\mathrm{CI}$, confidence interval 
medRxiv preprint doi: https://doi.org/10.1101/2021.06.24.21258830; this version posted June 25, 2021. The copyright holder for this preprint (which was not certified by peer review) is the author/funder, who has granted medRxiv a license to display the preprint in perpetuity.

All rights reserved. No reuse allowed without permission.

\section{Supplementary appendix}

\section{Comparison of PWID who participated in both programs vs. those who participated only in 2012-2013.}

To assess differential loss to follow-up, we compared the characteristics of PWID who participated in both programs versus those who participated only in ARISTOTLE 20122013. Compared to the total sample of participants of ARISTOTLE 2012-2013, repeat participants were younger (mean (SD): 35.0 (7.5) vs. $36.0(8.5), \mathrm{p}=0.004)$, more frequently females $(18.7 \%$ vs. $14.6 \%, \mathrm{p}=0.010)$, of Greek origin $(94.9 \%$ vs. $81.4 \%$, $\mathrm{p}<0.001)$, with stable accommodation (83.8\% vs. $75.1 \%, \mathrm{p}<0.001)$, with history of imprisonment ( $21.9 \%$ vs. $17.7 \%, \mathrm{p}=0.013)$, reported more often sharing syringes in the past 12 months ( $40.8 \%$ vs. $35.9 \%, \mathrm{p}=0.018$ ) and having been tested for HIV within the past year $(50.9 \%$ vs. $44.6 \%, \mathrm{p}=0.011)$ (Supplementary Table 1$)$. 
medRxiv preprint doi: https://doi.org/10.1101/2021.06.24.21258830; this version posted June 25, 2021. The copyright holder for this preprint (which was not certified by peer review) is the author/funder, who has granted medRxiv a license to display the preprint in perpetuity.

All rights reserved. No reuse allowed without permission.

Supplementary Table 1. Comparison of characteristics of PWID participating in both programs $(\mathrm{N}=681)$ versus those participating only in ARISTOTLE 2012-2013 $(\mathrm{N}=2,639)$ to assess differential loss to follow-up (characteristics were assessed in their first visit in ARISTOTLE 2012-2013).

\begin{tabular}{|c|c|c|c|}
\hline & $\begin{array}{r}\text { Both } \\
\text { programs } \\
(\mathrm{N}=681)\end{array}$ & $\begin{array}{r}\text { Only in } \\
\text { ARISTOTLE } \\
2012-2013 \\
(\mathbf{N}=\mathbf{2 , 6 3 9})\end{array}$ & p-value \\
\hline \multicolumn{4}{|l|}{$\begin{array}{l}\text { A. Socio-demographic and network } \\
\text { characteristics }\end{array}$} \\
\hline Age (years), mean (SD) & $35.0(7.5)$ & $36.0(8.5)$ & 0.004 \\
\hline Gender, n (\%) & & & 0.010 \\
\hline Male & $554(81.4)$ & $2253(85.4)$ & \\
\hline Female & $127(18.7)$ & $386(14.6)$ & \\
\hline \multicolumn{4}{|l|}{ Country of origin, $n(\%)$} \\
\hline Greece & $646(94.9)$ & $2147(81.4)$ & $<0.001$ \\
\hline Other & $35(5.1)$ & $492(18.6)$ & \\
\hline $\begin{array}{l}\text { Highest completed level of education, } n \\
(\%)\end{array}$ & & & 0.342 \\
\hline Middle/secondary school or below & $402(59.7)$ & $1509(57.7)$ & \\
\hline High school or higher level & $271(40.3)$ & $1106(42.3)$ & \\
\hline Homeless now, n (\%) & & & $<0.001$ \\
\hline No & $570(83.8)$ & $1977(75.1)$ & \\
\hline Yes & $110(16.2)$ & $655(24.9)$ & \\
\hline Without health insurance, n (\%) & & & 0.153 \\
\hline No & $259(38.3)$ & $927(35.3)$ & \\
\hline Yes & $418(61.7)$ & $1699(64.7)$ & \\
\hline $\begin{array}{l}\text { History of imprisonment (past } 12 \text { months), } \\
\text { n }(\%)\end{array}$ & & & 0.013 \\
\hline No & $529(78.1)$ & $2164(82.3)$ & \\
\hline Yes & $148(21.9)$ & $465(17.7)$ & \\
\hline
\end{tabular}


medRxiv preprint doi: https://doi.org/10.1101/2021.06.24.21258830; this version posted June 25, 2021. The copyright holder for this preprint (which was not certified by peer review) is the author/funder, who has granted medRxiv a license to display the preprint in perpetuity.

\begin{tabular}{lrr}
\hline $\begin{array}{l}\text { Size of participant's injection network, } \\
\text { median (25th, 75th) }\end{array}$ & $30(10,50)$ & 0.131 \\
\hline B. Injecting drug use behaviour & & \\
\hline Main substance of use (past 12 months), $\mathbf{n}$ & & \\
$(\boldsymbol{\%})$ & $549(80.7)$ & $2151(82.2)$ \\
\hline Heroin/Thai & $113(16.6)$ & $349(13.3)$ \\
Cocaine & $14(2.1)$ & $78(3.0)$ \\
Speedball & $4(0.6)$ & $38(1.5)$ \\
Other & &
\end{tabular}

Injecting drug use in the past 30 days, $n$

$(\%)$

0.724

\begin{tabular}{lccr}
\hline No & $124(18.3)$ & $497(18.9)$ & \\
Yes & $554(81.7)$ & $2135(81.1)$ & \\
\hline Duration of injecting drug use (years), & $13(8,18)$ & $12(6,19)$ & 0.544 \\
median (25th, 75th) & & &
\end{tabular}

Daily injecting drug use (past 12 months),

n $(\%)$

\begin{tabular}{lll}
\hline No & $434(63.8)$ & $1619(61.5)$ \\
Yes & $246(36.2)$ & $1014(38.5)$
\end{tabular}

Receptive syringe-sharing Sharing (past

12 months, n (\%)

Never or rarely

$402(59.2)$

$1682(64.1)$

About half the time or more

$277(40.8)$

$942(35.9)$

Use drugs divided with a syringe that

someone else had already injected with

(past 12 months), n (\%)

Never or rarely

$615(91.1)$

2415 (92.2)

About half the time or more

$60(8.9)$

204 (7.8)

C. Access to testing, drug treatment and

prevention

Currently in opioid substitution

treatment, n (\%) 
medRxiv preprint doi: https://doi.org/10.1101/2021.06.24.21258830; this version posted June 25, 2021. The copyright holder for this preprint (which was not certified by peer review) is the author/funder, who has granted medRxiv a license to display the preprint in perpetuity.

All rights reserved. No reuse allowed without permission.

Yes

$93(13.8)$

$316(12.2)$

\section{Received syringes through prevention}

activities (past 12 months), n (\%)

No

Yes

Tested for HIV, n (\%)

Within past year

More than 1 year ago

Never tested
327 (48.2)

$352(51.8)$
1308 (49.7)

$1323(50.3)$

$344(50.9) \quad 1163(44.6)$

$124(18.3) \quad 511(19.6)$

208 (30.8)

933 (35.8) 
medRxiv preprint doi: https://doi.org/10.1101/2021.06.24.21258830; this version posted June 25, 2021. The copyright holder for this preprint (which was not certified by peer review) is the author/funder, who has granted medRxiv a license to display the preprint in perpetuity.

All rights reserved. No reuse allowed without permission.

Supplementary Figure 1. Time at risk for 57 people who inject drugs with HIV seroconversion during the period 2014-2020. Each line corresponds to a seroconverter. The red symbol indicates the seroconversion date estimated assuming that the seroconversion time occurs in the midpoint of the seroconversion interval (last negative and first positive HIV test result). The blue symbol indicates an HIV(-) test result in the corresponding date. The gray zone indicates the duration of ARISTOTLE HCV-HIV program.

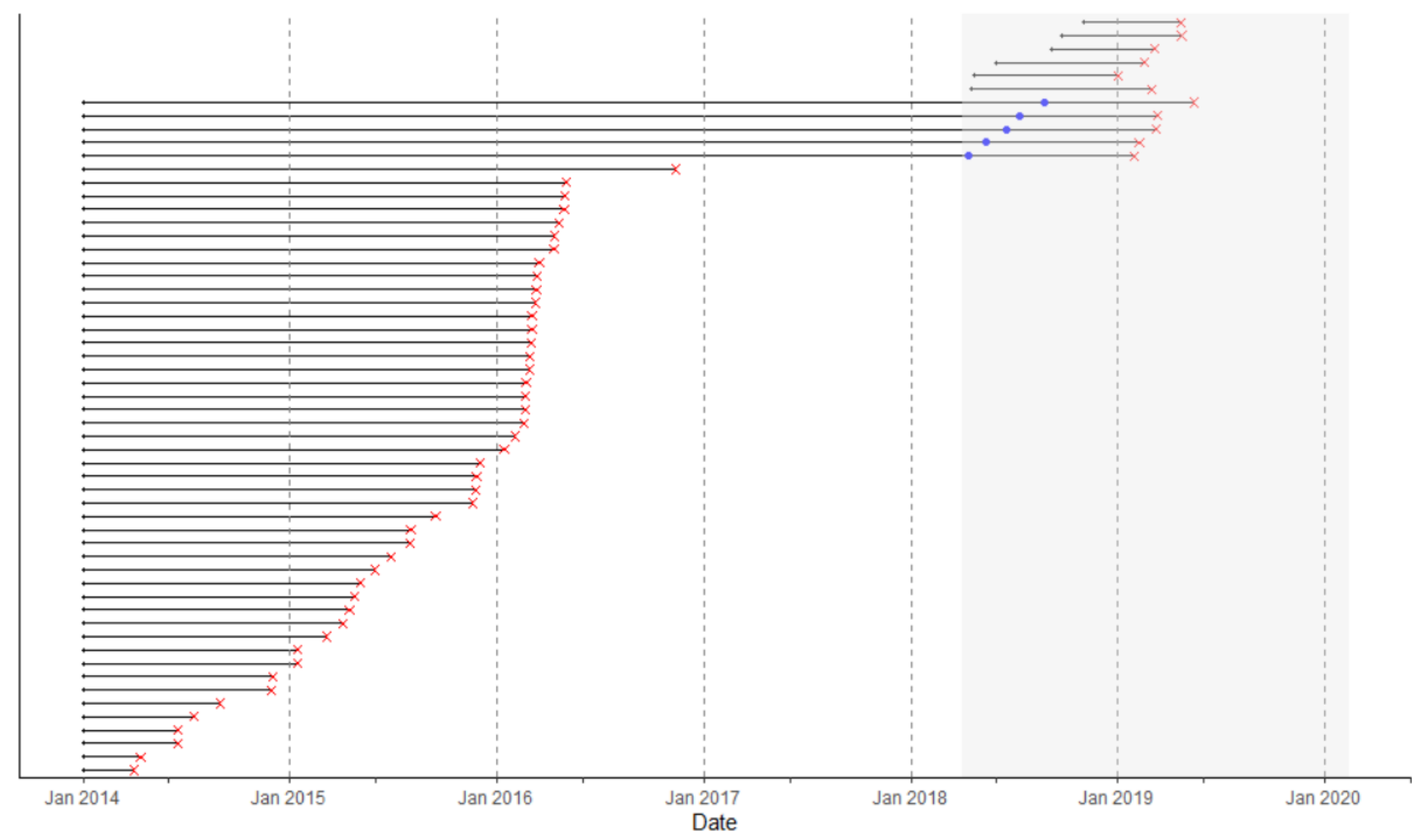


medRxiv preprint doi: https://doi.org/10.1101/2021.06.24.21258830; this version posted June 25, 2021. The copyright holder for this preprint (which was not certified by peer review) is the author/funder, who has granted medRxiv a license to display the preprint in perpetuity.

All rights reserved. No reuse allowed without permission.

Supplementary Figure 2. Incidence rate of HIV infection during the period August 2012-February 2020 among people who inject drugs. The first four estimates for the outbreak period August 2012-December 2013 were obtained from ${ }^{4}$.

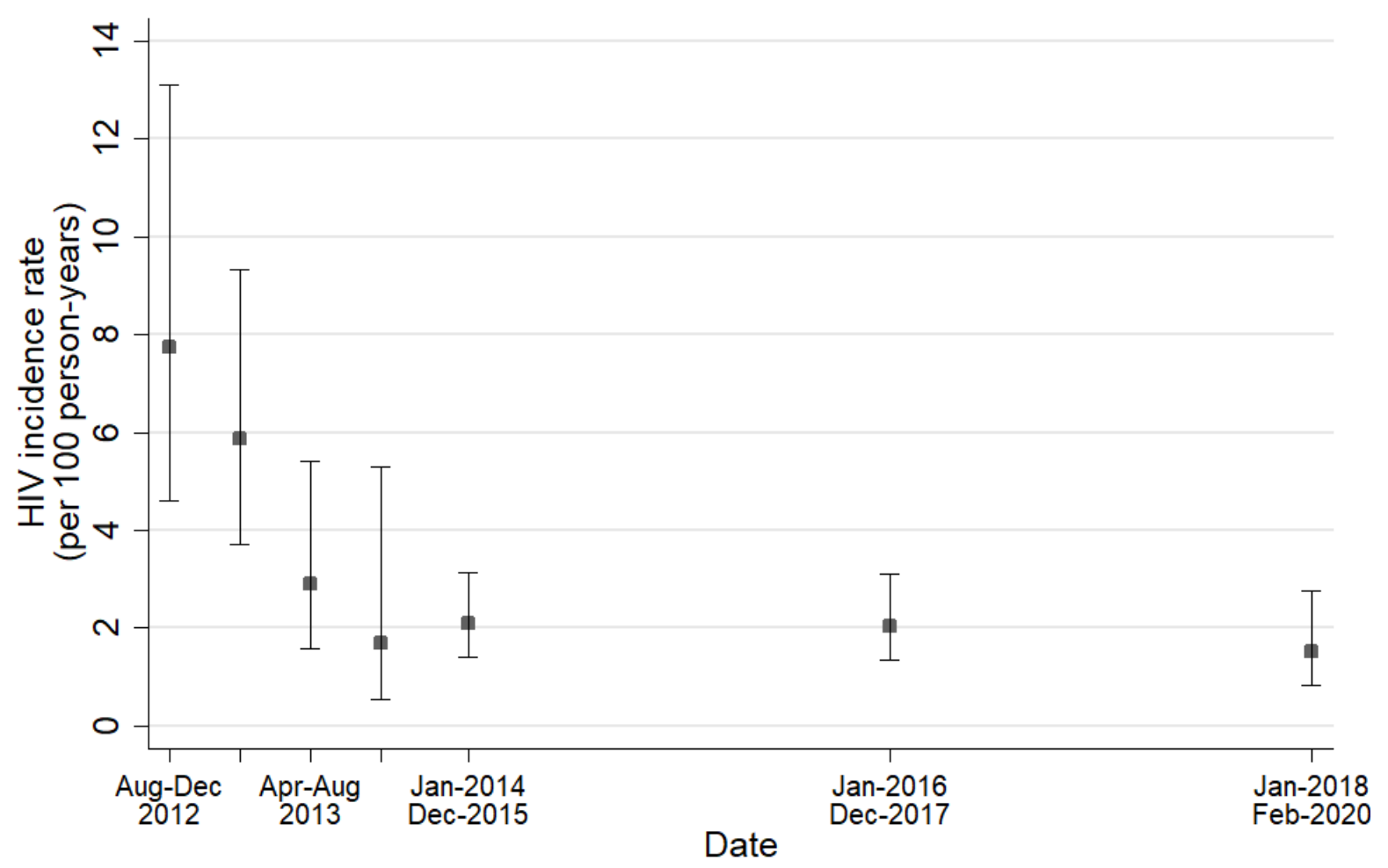

- Point estimate $\longmapsto 95 \% \mathrm{Cl}$ 